\title{
Clinical Significance of Increased Serum Levels of Troponin I in Patients from the Emergency Department of a County Hospital
}

\author{
PAUL-MIHAI BOARESCU ${ }^{1,2}$, IOANA CHIRILA ${ }^{3}$, ADRIANA ELENA BULBOACA ${ }^{1 *}$, \\ RAZVAN OLIMPIU MADA ${ }^{4}$, CERASELA MIHAELA GOIDESCU ${ }^{5}$, DIANA LARISA MOCAN-HOGNOGI ${ }^{5}$, \\ ALINA BUZURIU ${ }^{6}$, ADINA MARIA DAVID ${ }^{6}$, ANDREEA COTUT ${ }^{6}$, LUMINITA ANIMARIE VIDA-SIMITI ${ }^{5,6}$ \\ ${ }^{1}$ Iuliu Haţieganu University of Medicine and Pharmacy Cluj-Napoca, Department of Pathophysiology, 8 Victor Babes Str., \\ 400012, Cluj-Napoca, Romania \\ ${ }^{2}$ Iuliu Haţieganu University of Medicine and Pharmacy Cluj-Napoca, Department of Medical Informatics and Biostatistics, \\ 8 Victor Babes Str., 400012, Cluj-Napoca, Romania \\ ${ }^{3}$ County Clinical Emergency Hospital of Cluj-Napoca, Department of Neurology, 43 Victor Babes Str., 400012, Cluj- \\ Napoca, Romania \\ ${ }^{4}$ Nicolae Stancioiu Heart Institute, 19-21 Calea Motilor Str., 400001, Cluj-Napoca, Romania; \\ ${ }_{5}^{5}$ Iuliu Hatieganu University of Medicine and Pharmacy Cluj-Napoca, Department of Internal Medicine, 8 Victor Babes \\ Str., 400012, Cluj-Napoca, Romania \\ ${ }^{6}$ County Clinical Emergency Hospital of Cluj-Napoca, Department of Cardiology, 3-5 Clinicilor Str, Cluj Napoca, \\ Romania
}

\begin{abstract}
Elevated cardiac troponin I (cTnI) levels are diagnostic for myocardial injury. Moreover, they are essential for risk stratification in patients with acute cardiac ischemia and heart failure. However, their usefulness is not limited to the previous clinical conditions. The aim of this study was to evaluate the clinical significance of cTnI levels in the emergency department.In 324 patients, out of the 4147 referred to the emergency department, serum levels of cTnI were evaluated and represented the study population. Subjects were divided into 2 groups: Group 1 (66 patients) with cTnI $\geq 0.04 \mathrm{ng} / \mathrm{mL}$ and Group 2 (258 patients) with cTnI level < $0.04 \mathrm{ng} / \mathrm{mL}$. The clinical characteristics, laboratory data, ECG findings, echocardiographic abnormalities and discharge diagnosis were compared between the two groups. Patients with cTnI $\geq 0.04 \mathrm{ng} / \mathrm{mL}$ had more often a history of ischemic heart disease, lower levels of oxygen saturation, higher levels of blood glucose, increased white blood cells count, higher heart rate and deeper ST-segment depressions on ECG. The most common discharge diagnosis was heart failure. Although an elevated level of cTnI is highly suggestive for myocardial injury, it should always be interpretated in the clinical context. Heart failure is an important diagnosis in patients with elevated cTnI levels.
\end{abstract}

Keywords: troponin I, Emergency Department, myocardial injury, heart failure

The troponin $\mathrm{C}(\mathrm{cTnC}), \mathrm{I}(\mathrm{cTnI})$ and $\mathrm{T}(\mathrm{cTnT})$ are cardiac-specific structural proteins of the myofilaments that regulate muscle contraction [1]. These proteins are released into the blood circulation if myocardium cells are damaged by acute ischemia or any other mechanism that can lead to injury [2]. Due to their high sensitivity cTnT and cTnI (Figure 1) are more specific than creatine kinase (CK) for detecting myocardial injury according to the fourth universal definition of myocardial infarction $[3,4]$.<smiles>CC(=O)NCC(=O)N[C@@H](CCCCN)C(=O)NC(Cc1ccccc1)C(=O)N[C@@H](CCCCN)C(=O)NC(CCCNC(=N)N)C(=O)N1CCC[C@H]1C(=O)N1CCC[C@H]1C(=O)N[C@@H](CC(C)C)C(=O)N[C@@H](CCCNC(=N)N)C(=O)N[C@@H](CCCNC(=N)N)C(=O)NC(C(=O)N[C@@H](CCCNC(=N)N)C(N)=O)C(C)C</smiles>

Fig. 1. Cardiac Troponin I (cTnI) structure [5]

The major limitation of the standard cTns assays seems to be their low sensitivity during the first few hours after myocardial infarction [2]. The sensitivity approaches $100 \%$ by 6 to 12 hours after admission [6]. Troponin measurement is a useful instrument for risk stratification in all patients with acute cardiac ischemia, which increases the risk of major cardiovascular death in both short-term (30 days) and long-term (12 months) [7]. The aim of the study is to evaluate the clinical significance of cTnI in the emergency department (ED).

*email: adriana_bulboaca@yahoo.com 


\section{Experimental part}

We performed a transversal study by analyzing medical record data from consecutive patients admitted to the Emergency Department (ED) of the Emergency Clinical County Hospital Cluj-Napoca in December 2016. TnI measuring was the only inclusion criterion. From 4147 patients admitted to ED, 324 subjects $(7.81 \%)$ were included in the study. TnI was measured in patients with chest pain, history of myocardial infarction (MI), percutaneous coronary intervention (PCI) or coronary artery bypass graft (CABG), or in patients with unexplained dyspnea.

The laboratory markers analyzed in blood were: troponin I, NT-proBNP using a compact immunoanalyzer with superior assay performance (PATHFAST, MITSUBISHI CHEMICAL EUROPE), aspartate aminotransferase (ASAT), alanine aminotransferase (ALAT), creatinine, blood urea nitrogen, (using a FUJI DRI-CHEM NX 500 analyzer) glucose, $\mathrm{Na}+, \mathrm{K}+$, (using RAPIDPoint 500 Siemens Healthcare Diagnostics), red blood cells (RBC) count, hemoglobin (Hb), white blood cells (WBC) count and platelets (PLT), (using Swelab Alfa Plus system) while creatine kinase $(\mathrm{CK})$ and creatine kinase-MB (CK-MB) determination was performed at the local laboratory. Blood urea nitrogen has been converted to serum urea by multiplying by 0.357 . Glomerular filtration rate (GFR) was calculated according to the Cockroft-Gault formula [8]. At the time of admission, a standard 12-lead resting electrocardiogram (ECG) was recorded. ECG reading was performed by only one cardiologist for all patients. The sum of the STsegment depressions in all leads ( $\Sigma \mathrm{STd}$ ) and the sum of the ST-segment elevations in all leads ( $\Sigma \mathrm{STe}$ ) were also calculated for each patient. Echocardiography was performed by the cardiologist on duty, regional wall motion abnormalities (RWMA) and valvulopathies were evaluated.

We divided the patients into two groups: Group 1 if one value of TnI was $\geq 0.04 \mathrm{ng} / \mathrm{mL}$, while in Group 2 the values are $<0.04 \mathrm{ng} / \mathrm{mL}$. Groups were compared according to several demographic characteristics, cardiovascular risk factors and history of cardiac diseases, symptoms, major clinical findings, major electrocardiograph and echocardiographic data.

\section{Statistical analysis}

Mean \pm standard deviation were calculated for continuous variables and median (in the form Q1-Q3) for variables proved not to be normally distributed. Absolute and relative frequencies were used for categorical variables. Comparison between groups was performed with unpaired Student's t-test or Mann-Whitney test for continuous variables, while chi-square test and Fisher's exact test were used for categorical comparisons of data. $\mathrm{P}$ values of less than 0.05 were considered to indicate statistical significance. Receiver operating characteristic (ROC) curves were plotted and statistical indexes, such as area under the curve (AUC), sensitivity and specificity, were calculated. All statistical analyses were performed using SPSS software version 20.

\section{Ethics}

The study was approved by the Ethics Committee of the Iuliu Hatieganu University of Medicine and Pharmacy Cluj-Napoca. All patients signed an informed consent with respect to Romanian laws [9].

\section{Results and discussions}

Serum levels of cTnI were $0.132(0.065-0.585) \mathrm{ng} / \mathrm{mL}$ in Group 1 (66 patients) and $0.003(0.001-0.01) \mathrm{ng} / \mathrm{mL}$ in Group 2 (258 patients) with significant differences between groups $(\mathrm{p}<0.001)$.

Cardiovascular risk factors, history of cardiac disease were found in similar proportions of females and males and also with no significant differences regarding the history of percutaneous coronary intervention and coronary artery bypass graft. Patients with elevated levels of cTnI were older; more of them had diabetes, dyslipidemia, history of ischemic heart disease (IHD) and old myocardial infarction (old MI). Oxygen saturation level was lower in Group 1 as compared with Group $2(\mathrm{p}=0,026)$ (Table 1). Among all patients included in the study, $126(38.9 \%)$ did not report chest pain, 93 (28.7\%) reported a chest pain classified as nonspecific chest pain, whereas $54(16.7 \%)$ and $51(15.7 \%)$ respectively atypical or typical angina. Regarding the associated symptoms, $112(34.6 \%)$ complaint of dyspnea and 26 (8\%) had been experiencing palpitations. Patients from Group 1 had significantly elevated levels of CK (66.6\%), CKMB (66.6\%), NT pro-BNP (82.1\%) and also higher levels of glucose, ASAT, ALAT, and WBC as compared to Group 2 (Table 2). Heart rate on ECG was higher in patients from Group 1 (92.2 beats/min) as compared to Group 2 (84.3 beats $/ \mathrm{min})(\mathrm{p}=0.028)$. Patients with elevated plasma cTnI levels had higher ST-segment depression on the anterior wall $(2.5 \pm 0.7 \mathrm{~mm}$ vs $1 \pm 0.4 \mathrm{~mm}, \mathrm{p}=0.017)$. $\Sigma \mathrm{STd}$ in patients from the first group was higher $(0.52 \mathrm{~mm}$ vs $0.11 \mathrm{~mm}$, $\mathrm{p}=0.018)$. Of all subjects included in the study, $200(61.7 \%)$ were evaluated by the cardiologist on duty and echocardiography was performed to 181 (55\%) patients. Patients from Group 1 had more echocardiographic abnormalities as compared to patients from Group 2: regional wall motion abnormalities $(79.3 \%$ vs $20.7 \%, \mathrm{p}<0.001)$, mitral regurgitation $(53 \%$ vs $22.9 \%, \mathrm{p}<0.001)$, aortic stenosis $(18.2 \%$ vs $5.8 \%, \mathrm{p}=0.001)$ and tricuspid regurgitation $(31.8 \%$ vs $8.9 \%, \mathrm{p}<0.001)$. The most common discharged diagnosis was heart failure (HF) followed by arrhythmia and atypical or non-coronary pain (Table 3). HF was more frequent in Group 1, while atypical or non-coronary pain and pneumonia were more frequent in patients from Group 2. Patients with HF had 2.2-fold increased odds to 
Table 1

BASELINE CHARACTERISTICS AND CLINICAL FEATURES OF THE STUDY POPULATION

\begin{tabular}{|c|c|c|c|}
\hline Characteristics & $\begin{array}{l}\text { Group } 1 \\
(\mathrm{n}=66)\end{array}$ & $\begin{array}{l}\text { Group } 2 \\
(\mathrm{n}=258)\end{array}$ & $P$ \\
\hline Men, $\mathrm{n}(\%)$ & $38(57.6)$ & $127(49.2)$ & \multirow{2}{*}{0.226} \\
\hline Women, $\mathrm{n}(\%)$ & $28(42.4)$ & $131(50.8)$ & \\
\hline $\begin{array}{l}\text { Age at baseline examination } \\
\text { (years) }\end{array}$ & $70 \pm 12$ & $66 \pm 14$ & 0.030 \\
\hline \multicolumn{4}{|l|}{ Cardiovascular risk factors } \\
\hline Diabetes, $\mathrm{n}(\%)$ & $26(39.4)$ & $59(22.9)$ & 0.006 \\
\hline Hypertension, n (\%) & $48(72.4)$ & $163(63.2)$ & 0.146 \\
\hline Dyslipidemia, n (\%) & $19(28.8)$ & $44(17.1)$ & 0.032 \\
\hline \multicolumn{4}{|l|}{ History of cardiac diseases } \\
\hline $\mathrm{IHD}, \mathrm{n}(\%)$ & $39(59.1)$ & $108(41.9)$ & 0.012 \\
\hline Old MI, n (\%) & $16(24.2)$ & $33(12.8)$ & 0.020 \\
\hline PCI, n (\%) & $5(7.6)$ & $22(8.5)$ & \\
\hline $\mathrm{CABG}, \mathrm{n}(\%)$ & $3(4.5)$ & $6(2.3)$ & \\
\hline \multicolumn{4}{|l|}{ Clinical feauters } \\
\hline Body-mass-index $\left(\mathrm{kg} / \mathrm{m}^{2}\right)$ & $28.3 \pm 6.3$ & $27.6 \pm 5$ & 0.400 \\
\hline Systolic pressure (mmHg) & $143 \pm 31$ & $147 \pm 27$ & 0.394 \\
\hline Diastolic pressure (mmHg) & $84 \pm 17$ & $83 \pm 16$ & 0.470 \\
\hline Pulse pressure & $59 \pm 25$ & $64 \pm 21$ & 0.113 \\
\hline Oxygen saturation (\%) & $95 \pm 5$ & $96 \pm 4$ & 0.026 \\
\hline
\end{tabular}

Table 2

LABORATORY DATA IN THE TWO GROUPS

\begin{tabular}{|l|c|c|c|}
\hline Characteristics & $\begin{array}{c}\text { Group 1 } \\
(\mathrm{n}=66)\end{array}$ & $\begin{array}{c}\text { Group } 2 \\
(\mathrm{n}=258)\end{array}$ & P \\
\hline CK $(\mathrm{U} / \mathrm{L})$ & $381.0(87-650)$ & $82.5(53-114.5)$ & 0.000 \\
\hline CK-MB $(\mathrm{U} / \mathrm{L})$ & $31.5(22.25-76.25)$ & $18.0(12-27)$ & 0.001 \\
\hline Glucose (mg/dL) & $153.5(111.5-213.25)$ & $122.5(101.75-158)$ & 0.935 \\
\hline Creatinine (mg/dL) & $1.0(0.71-1.04)$ & $0.9(0.7-1.2)$ & 0.374 \\
\hline Urea (mg/dL) & $54.8 \pm 29.1$ & $50.5 \pm 36.3$ & 0.152 \\
\hline GFR (mL/min/1.73 m $\left.{ }^{2}\right)$ & $74.9 \pm 46.1$ & $83.6 \pm 42.8$ & 0.000 \\
\hline ASAT (U/L) & $34(24-62)$ & $23(18-33)$ & 0.014 \\
\hline ALAT (U/L) & $54 \pm 11.7$ & $38 \pm 12.3$ & \\
\hline \hline
\end{tabular}




\begin{tabular}{|c|c|c|c|}
\hline $\mathrm{Na}+(\mathrm{mmol} / \mathrm{L})$ & $136.5 \pm 8.5$ & $137.6 \pm 5.9$ & 0.201 \\
\hline $\mathrm{K}+(\mathrm{mmol} / \mathrm{L})$ & $4.2 \pm 0.8$ & $4 \pm 0.6$ & 0.126 \\
\hline NT pro-BNP ${ }^{c}(\mathrm{pg} / \mathrm{mL})$ & $5768.5(2800.2-24195.2)$ & $2577.5(676.0-6980.5)$ & 0.004 \\
\hline $\operatorname{RBC}\left(10^{\wedge} 12 / L\right)$ & $4.44 \pm 0.7$ & $4.41 \pm 0.7$ & 0.991 \\
\hline $\mathrm{Hb}(\mathrm{g} / \mathrm{dL})$ & $13 \pm 1.8$ & $13.25 \pm 2.1$ & 0.512 \\
\hline WBC $\left(10^{\wedge} 9 / \mathrm{L}\right)$ & $10.8 \pm 3.6$ & $9.7 \pm 3.8$ & 0.033 \\
\hline $\operatorname{PLT}\left(10^{\wedge} 9 / \mathrm{L}\right)$ & $206.0 \pm 74$ & $200.0 \pm 72$ & 0.527 \\
\hline
\end{tabular}

Table 3

MAIN DISCHARGE DIAGNOSIS FROM THE ED

\begin{tabular}{|c|c|c|c|}
\hline $\begin{array}{c}\text { ED Diagnosis } \\
\mathrm{n}(\%)\end{array}$ & $\begin{array}{c}\text { Group } 1 \\
(\mathrm{n}=66)\end{array}$ & $\begin{array}{c}\text { Group 2 } \\
(\mathrm{n}=258)\end{array}$ & $\mathrm{P}$ \\
\hline $\begin{array}{c}\text { Heart failure } \\
105(32.4 \%)\end{array}$ & $\begin{array}{c}31 \\
(46.9 \%)\end{array}$ & $\begin{array}{c}74 \\
(28.6 \%)\end{array}$ & 0.008 \\
\hline $\begin{array}{c}\text { Arrhythmia } \\
70(21.6 \%)\end{array}$ & $\begin{array}{c}14 \\
(21.2 \%)\end{array}$ & $\begin{array}{c}56 \\
(21.7 \%)\end{array}$ & 0.000 \\
\hline $\begin{array}{c}\text { Atypical, or noncoronary pain; } \\
57(17.6 \%)\end{array}$ & $\begin{array}{c}2 \\
(3 \%)\end{array}$ & $(20.9 \%)$ & 0.277 \\
\hline $\begin{array}{c}\text { Pneumonia } \\
39(12.3 \%)\end{array}$ & $\begin{array}{c}6 \\
(9 \%)\end{array}$ & $(12.7 \%)$ & \\
\hline $\begin{array}{c}\text { COPD } \\
33(10.1 \%)\end{array}$ & $(15.1 \%)$ & 23 & 0.105 \\
\hline
\end{tabular}

associate increased levels of cTnI (95\% CI, 1.26 to 3.83). Evaluating cTnI at presentation as a marker test in HF as compared to NT-proBNP, we found an AUC of 0.72 (95\% CI 0.62-0.82, p<0.001; Figure 2) for cTnI and an AUC of 0.85 (95\% CI 0.78-0.93, p<0.001; Figure 2) for NT-proBNP. Thus, the accuracy of cTnI as a marker of HF was not superior to traditional NT-proBNP (Figure 2).

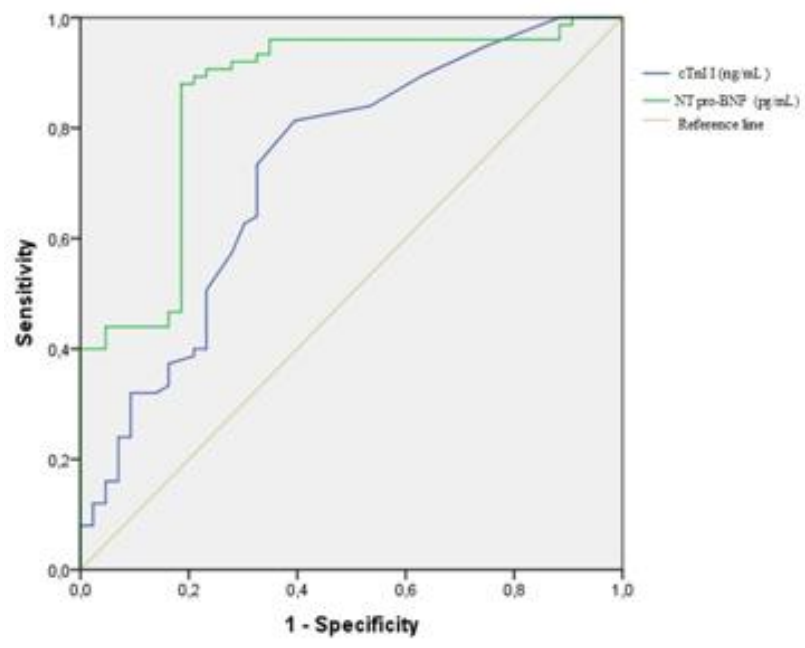

Fig. 2. Receiver operating characteristic curve analysis of cardiac troponin I (cTnI) and $\mathrm{N}$-terminal prohormone of brain natriuretic peptide (NT-proBNP) as markers for heart failure 
In Group 1, 20 patients (6.1\%) had NSTEMI and 13 patients (4.9\%) STEMI. In Group 2, 16 (6.2) patients had unstable angina pectoris. Overall, 249 (76.6\%) were admitted to the hospital, most of these 116 (46.5\%) went to cardiology departments and $40(16.0 \%)$ to internal medicine departments. In our study oxygen saturation level was lower in patients with elevated level of cTnI. In the absence of significant coronary artery disease, low oxygen level can result in cTn increase [10]. Elevated CK-MB in patients with elevated troponin is a result consistent with that of Fesmire [11] and Newby at al. [12]. The CK-MB is steel used as a marker of myocardial ischemia, [13] but with less specificity than cTnI [14]. Elevated serum aspartate and alanine aminotransferase (ASAT and ALAT) can be the result of acute hypoxic hepatitis due to acute cardiocirculatory failure or congestive hepatopathy in chronic HF [15]. HF progresses through necrosis and apoptosis. Patient with high level of NT-proBNP had also elevated level of troponin [16]. NT-proBNP is correlated with the degree of dysfunction in HF [17, 18]. Increased WBC count was proved to be a long-term predictor for mortality in patients with acute coronary events [19]. Activated monocytes and neutrophils could be an important source of free radicals involved in lipid peroxidation in the early phase after myocardial infarction [20]. Increased WBC count was proved to be an independent predictor for future cardiovascular events in patients with ischemic HF [21].Elevation of blood glucose is a common feature during the early phase after acute myocardial infarction even in the absence of a personal history of diabetes mellitus [22].

In our study cTnI was found elevated in patients with higher heart rate. One explanation was offered by Kanjwal et al. who concluded that troponins can be released because of tachycardia alone, in the absence of myocardial infarction or coronary artery disease [23].

$\Sigma$ STd was found to be a powerful independent predictor of 30 day death with a continuous increase in risk with the extent of ST-segment depression [24].The presence of wall motion abnormalities and the magnitude of this abnormality on echocardiography are important prognostic information on patients with acute myocardial infarction [25].

Patients with aortic stenosis had higher levels of troponin and in the study of Chin the levels of cTnI are correlated with LV mass index [26].

Elevated cTnI can be observed in both acute and chronic HF syndromes. Apart from myocardial ischemia, in HF syndromes, wall stress may directly lead to proteolysis of the cardiac contractile apparatus with troponin I release into the bloodstream [27]. In our study the diagnostic accuracy of cTnI in identifying patients with HF was modest (AUC 0.72) and inferior to NT proBNP. Our data and results of Arenja et al. do not support the use of cTnI as a diagnostic test for HF [28]. Elevated levels of cardiac troponins are common in patients admitted to hospital because of chronic obstructive pulmonary disease (COPD), especially in case of exacerbations related to acute coronary syndrome, patients with elevated cTnI required noninvasive ventilatory support more often than patients with lower levels. In theese patients cTnI was also identified to be a significant predictor of 18 -month overall survival for these patients [29].

The limitations of this study are mainly those inherent to single-center retrospective studies. It was not a randomized controlled trial, thus conclusions have to be drawn carefully. The ultimate etiology of the elevation in troponin I was established based on the discharge summary diagnoses.

\section{Conclusions}

A different pattern of the clinical feature was found in patients with increased cTnI. Although the elevated levels of cTnI are due to injury, related to primary myocardial ischemia, or supply-demand imbalance, the significance of elevated troponin I must be carefully interpreted in the clinical context of the patient, because many other multifactorial causes can determine myocardial injury. Heart failure is an important alternative explanation for an elevated cTnI level.

\section{Reference}

1.GALLI, C., LIPPI. G.. High-sensitivity cardiac troponin testing in routine practice: economic and organizational advantages. Ann Transl Med. 2016;4(13):257.

2. TANINDI, A., CEMRI, M. Troponin elevation in conditions other than acute coronary syndromes. Vasc Health Risk Manag. 2011;7:597603.

3. KORFF, S., KATUS, H.A., GIANNITSIS, E. Differential diagnosis of elevated troponins. Heart. 2006;92(7):987-93.

4.THYGESEN, K., ALPERT, J.S., JAFFE, A.S., CHAITMAN, B.R., BAX, J.J., MORROW, D.A. AND WHITE, H.D. Fourth universal definition of myocardial infarction (2018). J Am Coll Cardiol. 2018 Oct 22;72(18):2231-64

5. MEDKOO. [Internet]. MedKoo Biosciences, Inc. Morrisville (USA); [cited 2019 Jan 3]. Available from: https://medkoo.com/products/21479 6.PANTEGHINI, M., PAGANI, F., BONETTI, G. The Sensitivity of Cardiac Markers: an Evidence-based Approach. Clin Chem Lab Med. 1999;37(11-12):1097-106

7. BLANKEnBERG, S., SAlOMAA, V., MAKAROVA, N., OJEDA, F., WILD, P., LACKNER, K.J., JøRGENSEN, T., THORAND, B., PETERS, A., NAUCK, M., PETERSMANN, A. Troponin I and cardiovascular risk prediction in the general population: the BiomarCaRE consortium. Eur Heart J. 2016;37(30):2428-37.

8. ZAMORA, E., LUPÓN, J., VILA, J., URRUTIA, A., DE ANTONIO, M., SANZ, H., GRAU, M., ARA, J. BAYÉS-GENÍS, A. Estimated glomerular filtration rate and prognosis in heart failure: Value of the modification of diet in Renal Disease Study-4, chronic kidney disease epidemiology collaboration, and Cockroft-Gault formulas. J Am Coll Cardiol. 2012;59(19):1709-15. 
9. VIDA-SIMITI, I. Interventional Clinical and Chemical Studies in Romania, Legal Guarantees. Revista de chimie (Bucharest), 69, no.1, 2018, p 267-270

10. WOLFE BARRY, J.A., BARTH, J.H., HOWELL, S.J. Cardiac troponins: Their use and relevance in anaesthesia and critical care medicine. Contin Educ Anaesthesia, Crit Care Pain. 2008;8(2):62-6.

11. FESMIRE, F.M. Delta CK-MB outperforms delta troponin I at 2 hours during the ED rule out of acute myocardial infarction. Am J Emerg Med. 2000;18(1):1-8.

12. NEWBY, L.K., ROE, M.T., CHEN, A.Y., OHMAN, E.M., CHRISTENSON, R.H., POLLACK, C.V., HOEKSTRA, J.W., PEACOCK, W.F., HARRINGTON, R.A., JESSE, R.L., GIBLER, W.B. Frequency and clinical implications of discordant creatine kinase-MB and troponin measurements in acute coronary syndromes. J Am Coll Cardiol. 2006;47(2):312-8.

13. MYTHILI, S, MALATHI, N. Diagnostic markers of acute myocardial infarction (Review). Biomed Reports. 2015;743-8.

14. ADAMS, J.3., BODOR, G.S., DAVILA-ROMAN, V.G., DELMEZ, J.A., APPLE, F.S., LADENSON, J.H. JAFFE, A.S. Cardiac troponin I. A marker with high specificity for cardiac injury. Circulation. 1993;88(1):101-6.

15. KAVOLIUNIENE, A., VAITIEKIENE, A., CESNAITE, G. Congestive hepatopathy and hypoxic hepatitis in heart failure: A cardiologist's point of view. Int J Cardiol. 2013;166(3):554-8.

16. JERNBERG, T., STRIDSBERG, M., VENGE, P. AND LINDAHL, B. N-terminal pro brain natriuretic peptide on admission for early risk stratification of patients with chest pain and no ST-segment elevation. J Am Coll Cardiol. 2002;40(3):437-45.

17. GOIDESCU, C.M., FARCAS, A.D., ANTON, F.P. VIDA-SIMITI, L.A. The Pattern of Ventricular Remodeling Influences the Level of Oxidative Stress in Heart Failure Patients. Rev. Chim., 68, no 7, 2017, p 1506

18. GOIDESCU, C.M., ANTON, F.P., LEUCUȚA, D.C., MIRCEA, P.A. VIDA-SIMITI, L.A. Serum level of apelin-13 negatively correlated with NT-proBNP in heart failure patients. Rev Rom Med Lab . 2016;24(4):399-412.

19. HOFFMAN, M., BLUM, A., BARUCH, R., KAPLAN, E. BENJAMIN, M. Leukocytes and coronary heart disease. Atherosclerosis. 2004;172(1):1-6.

20. DURDEVIĆ, P.M., BASKIĆ, D.D., DUKIĆ, A., POPOVIĆ, S., JAKOVLJEVIĆ, V. ARSENIJEVIC, N.N. Phagocytic activity of peripheral blood leukocytes during acute myocardial infarction. Med Pregl. 2003;56 Suppl 1:97-102.

21. FARCAS, A.D., STOIA, M.A., ANTON, F.P., HOGNOGI, D.M., IANOS, R.D., HOJDA, S.E.S., GAVRILA, I.L., LUTAC, D., BURIAN, I.I. VIDA-SIMITI, L.A. The Lymphocyte Count and Neutrophil / lymphocyte Ratio are Independent Predictors for Adverse Cardiac Events in Ischemic Heart Failure but not with Non-ischemic Heart Failure. Rev. Chim., 67, no.10, 2016, p 2091.

22. ISHIHARA M. Acute Hyperglycemia in Patients With Acute Myocardial Infarction. Circ J. 2012;76(3):563-71.

23.KANJWAL, K., IMRAN, N., GRUBB, B. KANJWAL, Y. Troponin elevation in patients with various tachycardias and normal epicardial coronaries. Indian Pacing Electrophysiol J. 2008; 8(3): 172-174

24. SAVONITTO, S., COHEN, M.G., POLITI, A., HUDSON, M.P., KONG, D.F., HUANG, Y., PIEPER, K.S., MAURI, F., WAGNER, G.S., CALIFF, R.M. TOPOL, E.J. Extent of ST-segment depression and cardiac events in non-ST-segment elevation acute coronary syndromes. Eur Heart J. 2005;26(20):2106-13.

25.GIBSON, R.S., BISHOP, H.L., STAMM, R.B., CRAMPTON, R.S., BELLER, G.A. MARTIN, R.P. Value of early two dimensional echocardiography in patients with acute myocardial infarction. Am J Cardiol. 1982;49(5):1110-9.

26. CHIN, C.W., SHAH, A.S., MCALLISTER, D.A., JOANNA COWELL, S., ALAM, S., LANGRISH, J.P., STRACHAN, F.E., HUNTER, A.L., MARIA CHOY, A., LANG, C.C. WALKER, S. High-sensitivity troponin i concentrations are a marker of an advanced hypertrophic response and adverse outcomes in patients with aortic stenosis. Eur Heart J. 2014;35(34):2312-21.

27. JANUZZI JR, J.L., FILIPPATOS, G., NIEMINEN, M. AND GHEORGHIADE, M. Troponin elevation in patients with heart failure: On behalf of the third Universal Definition of Myocardial Infarction Global Task Force: Heart Failure Section. Eur Heart J. 2012;33(18):2265-71.

28. ARENJA, N., REICHLIN, T., DREXLER, B., OSHIMA, S., DENHAERYNCK, K., HAAF, P., POTOCKI, M., BREIDTHARDT, T., NOVEANU, M., STELZIG, C. HEINISCH, C. Sensitive cardiac troponin in the diagnosis and risk stratification of acute heart failure. J Intern Med. 2012;271(6):598-607.

29. NOORAIN, S. Prognostic value of cardiac troponin I during acute exacerbation of chronic obstructive pulmonary disease: A prospective study. Lung India. 2016;33(1):53-7.

Manuscript received: 11.02 .2019 